\title{
Vietnam's Confucianism within the Dynamics of Globalization
}

\section{El confucianismo de Vietnam en las dinámicas de la globalización}

DOI: $10.32870 /$ mycp.v10i30.732

\author{
Cid Marco Riveros Lozano ${ }^{1}$
}

\begin{abstract}
The objective of this article is to further the study of Confucianism and its distinct expressions, focusing on Vietnam's case, where it is proposed that Confucianism has followed an exceptional path from its origin, in China's Shandong peninsula 2,600 years ago, up to its adoption by Vietnamese society. In the article, it is hypothesized, through a geopolitical analysis and particularly David Harvey's uneven geographical developments, that Confucianism in practice, even if already implanted within certain structures of the Vietnamese society, has been displaced in the areas where globalization has impacted the most. Nevertheless, after having concluded the analysis, said hypothesis is discarded; although, given the rapid changes Vietnamese society is undergoing, future investigations may prove otherwise.
\end{abstract}

Keywords: Confucianism, China, Vietnam, geopolitical analysis, globalization.

\begin{abstract}
Resumen
El objetivo del presente artículo es profundizar en el estudio del confucianismo y sus distintas expresiones, poniendo énfasis en el caso de Vietnam, en donde se propone que el confucianismo ha seguido un camino excepcional desde su origen en la península Shandong de China hace 2,600 años, hasta su adopción por la sociedad vietnamita. En el artículo se hipotetiza, por medio del análisis geopolítico y en particular los desarrollos geográficos desiguales de David Harvey, que la práctica del confucianismo, si bien ya implantada dentro de ciertas estructuras de la sociedad vietnamita, se ha visto desplazada en las áreas en donde el proceso de la globalización ha tenido mayor impacto. No obstante, luego de haber realizado el análisis, dicha hipótesis es descartada; a reserva de que, dados los rápidos cambios que están aconteciendo en la sociedad vietnamita, futuras investigaciones prueben lo contrario.
\end{abstract}

Palabras clave: confucianismo, China, Vietnam, análisis geopolítico, globalización.

\section{Introduction}

Confucianism, a 2,600 years old religion with its origin in China, ${ }^{2}$ can be unmistakably found all over East Asia: China itself, Korea, and Japan; but

Archivo recibido el 28 de noviembre de 2020 y dictaminado el 8 de marzo de 2021.

1. Universidad de Guadalajara. Centro Universitario de Ciencias Sociales y Humanidades. Licenciatura en Relaciones Internacionales. Av. Parres Arias 150, San José del Bajío, C. P. 45132. Zapopan, Jalisco, México. ORcID: https://orcid.org/0000-0002-4273-2977. E-mail: cidmarco.rl@gmail.com

2. More specifically, Chun-Chieh Huang (2018) locates Confucianism's origin "2,600 years ago on the Shandong Peninsula in China" (p. 76). 
looking further down on the Asian map, Confucianism can also be found on the South East Asian country of Vietnam. In a region typically considered heavily influenced by Indian culture, why is it that Vietnam stands out as the only Sinicized ${ }^{3}$ country of South East Asia, being Confucianism an undeniable sign of it?

A history of intense cultural exchanges - and even some impositionswith China, would be behind this apparently conflicting situation. Even within Vietnam itself, this South East Asian duality can be perceived, as Le Van Anh (2006) points out, "the northern area above eighteen degrees latitude belonging to the Chinese cultural sphere and the southern area belonging to the Indian cultural sphere" (p. 317).

In spite of this duality, Confucianism has been successfully assimilated into Vietnamese society. Popular practices and governmental efforts, on the long run, joined forces in their acceptance of Confucian principles and practices; all whilst adapting Confucianism to Vietnamese culture, making Vietnamese traditions inherently distinct of Chinese, Korean, or Japanese Confucianisms (Huang, 2018).

Nevertheless, the question of how does a millennia old religion, as adaptable as it may be, reacts to the new phenomena of globalization rests unsolved.

Frenetic change, vertiginous technological innovations, and instantaneous communications are some of the characteristics of globalization that are pushing societies all over the world to change and homogenize into a sort of capitalist and consumerist worldwide culture.

In short, this article will attempt to address the subject of how will Confucian practices be affected in the Vietnamese society due to globalization.

\section{Confucianism $-s-$}

When talking about Confucianism, it must be clear that it is no easy task to define what it actually is. As John Makeham (2003) plainly says it, "'Confucianism' has been variously applied to so many different things, (...) philosophical

3. Sinicization making reference to, as Liam C. Kelley (2006) writes: "the appropriation of the Confucian and other [Chinese] repertoires by people like the Vietnamese and Koreans" (p. 316). In other words, making reference to the state on which a culture has been heavily influenced by Chinese culture. 
and ethical teachings of a number of thinkers (...), a tradition of scholarship, a religion, a social ethic, and a state ideology" (p. 1).

To complicate even more its analysis, Pham Duy Nghia (2005) states that "although Confucius was the most famous teacher, he was not the creator of a new religion; the five classical works incorporated the wisdom of many generations"4 (p. 79). Then, how is it that Confucianism has arrived to its current point of development, if there is no clear definition of what it is?

To begin with this analysis, Daniel K. Gardner (2014), in his Very Short Introduction of Confucianism, sets a historical pathway to Confucius' life and work. Having lived during the sixth century BCE, Confucius is described to us as an individual who "would have preferred to live five hundred years earlier" (p. 1), dedicating his entire career to trying to convince the leaders of the then fragmented Chinese states, to return to the values of what he considered had been a golden age. His theorizations always point towards the value of a moral leadership, one of excellency and whose leaders would guide through example.

Unfortunately for Confucius himself, his teachings did not have much impact during his lifetime. Apart from his disciples, who would continue on to compile and transmit his teachings, no leader would embrace his ideals, a situation that made Confucius live in a state of unending disappointment (Gardner, 2014). Gardner also goes on to explain some of the reasons for his failure by explaining that "rulers of the day apparently found his ideas impracticable. After all, warfare among the competing states was constant in the sixth century (...) It is likely, too, that the Master's personality did not readily win over the feudal rulers" $(2014$, p. 3). Overall, one reason for Confucianism's initial lack of success, is that during the time of the Warring States there were many schools of thought competing to win the favor of the feudal rulers (e.g. Gardner, 2014; Nghia, 2005).

Nowadays, it remains unclear whether or not Confucius expected to start a new religion with his teachings; what is clear is that the work his disciples made with Confucius' legacy has passed into history as a success, proof of it being "that his name holds the place in history that it does" (Gardner, 2014, p. 3).

4. Even though Nghia doesn't clarify the names of these five texts, Daniel K. Gardner (2014) tells us that the names of the Five Classics are "the Book of Changes, the Book of Odes, the Book of History, the Book of Rites, and the Spring and Autumn Annals" (p. 4). 
Confucianism's situation within China would start changing "by the second century BCE, as Han - 202 BC-222 CE- rulers lent increasing support to Confucian teachings" (Gardner, 2014, p. 5). Chinese rulers would then proceed to embrace Confucianism and incorporate it into its structure, even getting to the creation of an examination system based on Confucianism for the recruitment of the government personnel (Gardner, 2014).

Now, how did Confucianism transcend Chinese frontiers? Kiri Paramore (2015) gives a pretty straightforward explanation to this question by stating that Confucianism only ever really spread to former Chinese tributary states - Korea and Vietnam - , that had been under Chinese political control; and Japan, as the only exception.

On another note, Chun-Chieh Huang (2018) gives an explanation that appeal to Confucianism's capacity to adapt to the different cultures it encounters. Huang develops the term "East Asian Confucianisms" as a "family of intellectual traditions" that, despite its regional particularities, retains the core values of Confucianism. A dynamic community that cannot recognise any single one of its manifestations as the superior one, discarding "such theoretical presuppositions as 'orthodox versus heterodox' or 'center versus periphery' " (Huang, 2018, p. 77).

At this point, it would be appropriate to go through the main variations that the Vietnamese gave to their Confucianism. Le Hong Hiep (2017) in his book Living Next to the Giant, goes through some of the main differences between Chinese and Vietnamese Confucianisms: Chinese Confucianism with "emphasis on internal stability (...) no or little recognition of women's social roles and rights (...) loyalty to rulers only (...) literatis are equally or less important than military generals (...) [and] merchants are respected" (Hiep, 2017, p. 21), as opposed to Vietnamese Confucianism with "emphasis on both internal and external stability (...) higher recognition of women's roles and rights (...) emphasis on both loyalty to rulers and patriotism/ nationalism (...) literatis are generally more important and better respected than generals (...) [and] merchants are disdained" (Hiep, 2017, p. 21).

Huang (2018) goes on to explain that the respective transmitters of Confucianism in China, Tokugawa Japan, and Joseon Korea were scholars, commoner intellectuals, and the yang-ban respectively. As for Vietnam, in this subject, Huang appears to make an ominous omission, making, perhaps, part of those who see Vietnam as a "little China", therefore explaining China would be explaining Vietnam. Hiep (2017), goes through great lengths to 
counter this perception that he calls the "little China fallacy" and writes that "Vietnam has been willing to borrow culturally from China as long as it was a voluntary, internal process rather than a forceful imposition from the north" (p. 16), a statement that will be reinforced through the next section, when the historical relationship of Vietnam with Confucianism - and China- is analyzed.

\section{Vietnam and its history with Confucianism — and China-}

Vietnam, in its relationship with China, has always been subject to the influence of its northern neighbour. As Thayer (2002) proposes it, "Vietnam suffers from 'the tyranny of geography'. Vietnam's population of nearly 80 million makes it roughly equivalent to a single middle-sized Chinese province" (p. 271).

All of these reasons factor into the aforementioned perception of the "little China fallacy", to the grade that in China, Vietnam is perceived as rebellious (Cesarín, 2014, as cited in Fornillo, 2016). On the other hand, Chinese ambitions keep growing, even today; this is proven by its attempts to enforce its claims on the South China Sea, a resource rich zone widely used by the trade routes that supply China; a sea that encompasses ten countries' maritime claims, ${ }^{5}$ amongst whom Vietnam can be found (Fornillo, 2016). Nonetheless, how has the Vietnam-China relationship arrived at this geopolitical reality?

Historically, the Vietnam-China relationship can be traced all the way back to the beginning of writing, for all over East Asia the Chinese logographic script was employed to write, even though in practice each country gave it its own variations $s^{6}$ (Ebrey et al., 2009). Later on, Vietnam and China would confront each other in a series of Chinese invasions to the northern part of Vietnam. Ultimately, "after almost a hundred years of diplomatic and military duels between the Han Dynasty and Nam Viet, Emperor Wu sent armies that conquered it in 111 b. c. e" (Ebrey et al., 2009, p. 53). Le Van Anh (2006) goes

5. The South China Sea encompasses: China, Taiwan, the Philippines, Vietnam, Cambodia, Malaysia, Brunei, Singapore, Thailand, and Indonesia; some of which potential allies of the United States (Fornillo, 2016).

6. In the case of Vietnam, this practice of employing the Chinese characters would disappear with the French colonization of Indochina, as mentioned by Nguyen Tuan Cuong (2015) in the phrase "as Confucian education in Cochinchina was subsequently replaced by French education during the colonial period, Chinese characters ceased to be used in the official system of education" (p. 34). 
on to specify that "the first major external pressure to Vietnam's existence was the conquest of the Red River Delta by Han China" (p. 316), an area in the north of Vietnam to which the Sinicization was limited; a notion that is further reinforced by Le Van Anh by writing that the 'Chams' a population of middle Vietnam, "are ethnically and culturally different from the Viets in the north" (p. 317).

During this period of Chinese domination, political institutions, language, art, architecture, and music were all imported as part of the Chinese rule over northern Vietnam, along with Confucianism (Ebrey et al., 2009, p. 53). Chinese rule in Vietnam would go on for almost a thousand years, but the sense of resistance would never really disappear. As Le Van Anh said, "paradoxically, the Sinicization process created a national consciousness in Vietnam that enabled the Vietnamese to resist Chinese political domination in later centuries" (2006, p. 316).

Going a couple years into the future, "by the end of the Tang dynasty in China, there was frequent resistance by a strong anti-Chinese group in Vietnam that overthrew Chinese rule in 939. Yet, Chinese cultural practices persisted" (Van Anh, 2006). Gardner (2014) explains that "Chinese culture -in the form of the Chinese writing system, Confucian texts and rituals, and Chinese-style administration - infiltrated Vietnamese life" (p. 9). Gardner also goes further in his explanation by saying that "the region was also introduced to the Confucian-based Chinese civil service examination system (...) [which would be employed in Vietnam] to recruit court officials until the 1910s" (2014, p. 9).

Besides, Nghia (2005) talks about a Confucian scholar class that "used Confucianism to fight against the Chinese occupiers (...) Thereafter, the social prestige of Confucian scholars improved" (p. 82). From that moment on, Confucianism was embraced by the Vietnamese elite and eventually proliferated to the villages through books and private Confucian schools (Nghia, 2005). Nghia also goes on to affirm that through the incorporation of different values of "Buddhism, Daoism and other natural beliefs (...) the population had already been practising Confucianism, albeit in an indirect manner" (2005, p. 82). It is on this note that Hiep's asseveration that "as Confucianism was forcefully imposed on Vietnamese people as a means of colonization and assimilation, it invited resistance (...) Meanwhile, during the age of national independence, Vietnamese dynasties voluntarily imported Confucianism for the purpose of nation-building and social management" (2017, pp. 18-19). 
On the other hand, how did Confucianism work in a country as culturally diverse as Vietnam? On this matter Brett Reilly affirms that the State of Vietnam "was a work of bricolage: the unanticipated collection of state projects and personalities left over from the recent past and conditioned by the fragmentary character of the modern Vietnamese state" (2016, p. 104).

It is key to remember that the northern part of Vietnam was heavily Sinicized through all the historical process of Chinese colonization of Vietnam, ${ }^{7}$ but the southern part of Vietnam remained more influenced by Indian culture, making it intrinsically different from the northern population. The addressed southern area of Vietnam is Nam Ky, later renamed by the French into Cochinchina (Hiep, 2017).

Cuong (2015), writes that "'Cochinchina' (...) is a relatively new territory for the Vietnamese, acquired in the seventeenth century through a historical process of Vietnam's southward expansion" (p. 34). Cuong also goes on to explain that, having been the last area incorporated into Vietnam, it also was the one less exposed to the Vietnamese system of Confucianist education, given that it only lasted fifty-two years in the region, in comparison with the 844 years in North Vietnam. This situation is due to the French, who replaced the educational system in 1864 (Cuong, 2015).

Moving forward in time, during the United States' occupation of South Vietnam and the creation of the Republic of Vietnam, following the Geneva Agreements of July 1954, ${ }^{8}$ Cuong identifies several factors and practices that favored the implementation of Confucian ideals in the South Vietnamese society. Cuong states that, as a result of modernization and the increasing westernization of South Vietnamese society, pressure was felt to maintain the "traditional cultural institutions, among which were aspects of Confucianism brought to the South by exiles from the North in 1954" (2015, p. 35). Besides, Cuong also points out, there were six groups of people who formed

7. Ebrey et al. (2009) define very well the process under which the Chinese occupation of the northern part of Vietnam constantly reflected a colonization. Practices like sending settlers, displacing or assimilating the local populations, establishing new — duplicated from China - structures of government and protecting their settlers through garrisons are some of the practices that strongly resemble a colonization.

8. Cuong (2015) also pinpoints that the Geneva Agreements of July 1954 were the ones that determined the partition of Vietnam into two separate states along the $17^{\text {th }}$ Parallel: North Vietnam or the Democratic Republic of Vietnam, with support of the Soviet Union, China, and basically the communist block of countries of the time; and South Vietnam or the Republic of Vietnam, supported by the United States and its anti-communist alliance. 
a Confucian circle: ${ }^{9}$ people with a Confucian background who would take it upon themselves to preserve and spread Confucianism in the South through different activities, such as "activities of social institutions, be they state institutions or private associations (...) [or] communal events" (2015, p. 41).

Finally, Cuong also identifies that, even though it is typically considered that Confucianism, Buddhism, and Daoism are the Vietnamese traditions, in the effort of modernizing whilst keeping true to their traditions, Confucianism received an extra impulse from the "political circle, particularly President Ngo Dinh Diem -1901-1963” (2015, p. 42).

Having briefly explained the origin of Confucianism in the whole country, it is now time to proceed to the actuality. The moment Duong Van Minh, the last president of the Republic of Vietnam, surrendered to the Democratic Republic of Vietnam (1975), Confucianism's stance within Vietnam would undergo drastic changes that $\mathrm{Ho} \mathrm{Chi}$ Minh and his controversially Confucian thought had started.

\section{Modern day Vietnam and Confucian practices}

As Nghia (2005) mentions it, "it is well known that Marx saw religion as the 'opium of the people' and an expression of the hope of the suppressed mass for a brighter future" (p. 78). Communist regimes have typically been enemies with religions and cultural practices that may represent a threat to their control; China, for example, went on several campaigns to discredit Confucianism and its famous scholars, even Confucius himself was made a target of these campaigns (Cuong, 2015).

The case of Vietnam, however, was different. As Nghia (2005) also tells us, "once in power, the Vietnamese Communists did not fight Confucianism as bitterly as did their Chinese counterparts, but the social prestige of Confu-

9. The six groups that Cuong identifies within the "Confucian circle" are the following ones: the "elder Confucians" of Hue; the elder Confucians of Sai Gon; the Confucian intellectuals; Chinese residents; some students; and, "intellectuals who acquired the spirit of the Confucian tradition" (2015, p. 36). 
cianism was essentially destroyed"10 (p. 83). Still, trouble does tend to appear when analysis starts pointing to the embracement of Confucian values by the Vietnamese Communist leaders.

Ho Chi Minh, the emblematic communist leader of North Vietnam, has been described as "the authentic embodiment of an ageless Vietnamese spirit based on Confucian values and peasant culture" (Reilly, 2016, p. 106), and critics within Vietnam have promptly critiqued these kinds of postures. Nam Nguyen (2018) narrates the case of the work of the Vietnamese "well known medical doctor and political activist Nguyen Khac Vien, who was seriously criticized in North Vietnam in the 1960s for figuring out, in an essay, Confucian elements in Ho Chi Minh's thought" (p. 128). It might be argued that the 1960s were a long time ago, but Nguyen also goes on to describe how Nguyen Khac Vien's work, Confucianisme et Marxisme au Vietnam [Confucianism and Marxism in Vietnam], would become his most successful piece of work and would be translated into several languages. And yet, the translation into Vietnamese and its consequent publication would not come until 1993 (Nguyen, 2018).

By quoting an appendix wrote by Nguyen Khac Vien (1993, cited in Nguyen, 2018), Nguyen (2018) writes an explanation as to why Communist politicians might have employed Confucianism to their advantage: "unlike other religions, [the aim of] Confucianism is to direct human beings' thought completely into social life; therefore it stands on the same page with Marxists" (p. 129). Nguyen, in the same quote of Nguyen Khac Vien, also says that "if we are able to convince a Confucian that Marxism can realize all the social ideals that he has ever thought of, this Confucian should be willing to decline Confucianism and accept Marxism" (p. 129). This is the way that the Communist revolutionary values could actually turn out to be Confucian pivotal virtues gone through a process of revolutionization (Nguyen, 2018). In short words, "Confucianism paved the way with auspicious conditions for the introduction of Marxism [into Vietnam]" (Vien, 1993, as cited in Nguyen, 2018, p. 129).

10. That is not to say that every religion had the same luck; religions perceived as more problematic continue to suffer some sort of discrimination. Bidwell and Schipani (2019) wrote that "it can be difficult for a Christian woman, for example, to marry a non-Christian man or someone employed by the military, police, or government; being married to a Christian [...] serves as a barrier to professional advancement" (p. 126). The authors attribute this to the fact that "some forms of Christianity advocate" (p. 125) are signalled as problematic for questioning well established Vietnamese social institutions. 
Overtime, due perhaps to this influence of the Communist Party over the perception of civil society on Confucianism, it is hard to know if the current virtues under which the Vietnamese live were revolutionary virtues, indigenous beliefs or Confucian values that were introduced and assimilated over the centuries. Nevertheless, these virtues can be observed in a multiplicity of spaces and some will be exemplified next.

Vietnam's legal system is increasingly influenced by the West since the opening of the country in the last part of the Xx century, ${ }^{11}$ a trend that can be appreciated in its neighbouring countries as well. The problem comes when, as Nghia (2005) explains it, the reforms adopted from the West are hardly compatible with Vietnamese social tradition, and therefore are not really enforced in practice. Nghia also goes on to explain that, given the prevalence of the use of social norms on the agricultural sector and the importance of it, these kinds of norms have a preponderance over laws and the legal system; social norms that, as Nghia says it, have a stunning resemblance with Confucian principles. ${ }^{12}$ Summarizing, "Confucianism not only substitutes for the law in many aspects of life, but also contributes heavily to the conception of the law in Vietnam" (Nghia, 2005, p. 76).

Continuing with the analysis of the different structures of Vietnamese society that have been influenced by the duality of Communism and its revolutionized Confucian values, the Vietnamese educational system, particularly in its high level, is a structure of society that has been thoroughly influenced. Thi Tuyet Tran (2013) gives an insight on the malfunctioning crucial structure for the training of workforce by writing that "paradoxically, despite the fact that each year thousands of students graduate, many having difficulties finding work, employers still complain that it is hard to find graduates with the required knowledge and skills" (p. 631). To give said malfunctioning an explanation, Tran writes that, despite the overture of the economy and the rapid development of the country, "the teaching in the HEs [Higher Education System] has still inherited many characteristics of the traditional teaching

11. In a move arguably similar to Gorbachev's Perestroika, Vietnam would implement its own economic reform under the name of Doi Moi on 1986 to adopt a market based economy. Hiep (2017) writes that the move was motivated by the Party's economic failures that were endangering its political survival.

12. Nghia (2005) recognises the next as social norms of the agricultural society of Vietnam: collectivism, rule of causality, life is to endure, harmony and consensus, not conflict, face saving and relationship keeping, respect for elders, Nhan-nghia - a concept that corresponds to Confucian ren-. 
method which strongly reflects both Confucian culture and the old Soviet top-down approach" (2013, p. 633).

On its own, this reflection of a past system would not have to be negative, but, as again Tran (2013) informs us, the system, despite having expanded after the economic reforms of Doi Moi, remains "under the firm control of the central government and the central ministry" (p. 633), limiting the teachings of the university students to the same values of the 1980s and early 1990s, prioritizing "obedience, hard-working, loyal and able to follow orders" (p. 633) and restricting the growth of the very much needed "creative and initiative people, who can work independently under pressure" (p. 633).

On the same subject, Tran (2013) points out that in Vietnam there is an over focus of the students on exam results and academic achievements, "misunderstanding that only good marks were the indicator of a good and successful student" (p. 638), therefore hindering their ability to take advantage of school activities to develop much needed skills. This particular practice can be traced back to the emphasis of Confucian practice on the evaluation system.

One of the reasons for the system staying this way is mentioned by Nghia (2005): "the backward-thinking style of Confucianism sometimes produced reactionary forces that opposed reform" (p. 82); Tran (2013) also gives a similar reasoning about Confucianism's influence on the educational system: “it [Confucianism] also prevents students' parents, who often have very important role and voice in student's study (...) from recognizing the change required in the society and in industry. They eventually become obstacles" (p. 640). These two factors may be related to Hiep's (2017) comment on the prerequisites for the development of a democracy, mentioning political culture and religious traditions as essential factors. Moreover, Hiep writes that "many scholars have argued that while Protestantism is favourable to the growth of democracy, Islam, Confucianism, as well as Catholicism in many cases, are less so" (p. 185). ${ }^{13}$

Even though the structural elements in Vietnamese society already give a hint of the importance that Confucian principles still hold within Vietnam, Avieli (2011) shows a completely different scale of this pattern by talking

13. Despite all these arguments that point at Confucianism as contrary to democracies, Doh Chull Shin (2011) arguments that Confucianism can be both considered compatible and antagonistic to the development of democracy according to an extensive bibliography of authors that have theorized on both ends of the spectrum. 
about Confucianism in the order in which people at a meal eat rice. "The very act of eating a meal shows respect toward rice and reproduces Confucian patterns of seniority and status in the order with which people take the first bite" (p. 222).

Overall, we can conclude this section with Nghia (2005), who says that despite the fact "that the Confucian tradition may have changed in appearance (...) the substance is still important in modern Vietnamese life". Despite all the alterations, destruction of social prestige, and the rapid changes of having an open market based economy, Confucianism rests as an essential part of Vietnam.

\section{Brief summary of geopolitical basics}

On the prelude to the final geopolitical analysis, it is important to clarify some of the geopolitical concepts that will be employed, primarily making use of David Harvey's uneven geographical developments, which he introduced on the year 2000 in his book Spaces of Hope. David Harvey, makes a very thorough critic of Marx and Engel's work, putting it up to date with the various contemporary dynamics of the globalising capitalistic world humanity is currently inhabiting.

To begin with this summary, Harvey (2000) gives globalization an interpretation of his own, calling it a capitalistic process in which the so-called spatial fixes ${ }^{14}$ are constantly employed as temporal solutions to the internal pressures generated by the capitalistic practice of capital accumulation in specific geographical areas. To achieve this, in the process of globalization, the bourgeoisie is constantly improving material capabilities to facilitate the process of accumulating capital and converting "the state - with its military, organizational, and fiscal powers - into the executive of its own ambitions" (p. 24).

In this same logic, Harvey (2020) mentions that, "internally, the creation of great cities and rapid urbanization rule over the country — simultaneously rescuing the latter from the 'idiocy' of rural life and reducing the peasantry to a subaltern class-” (pp. 24-25). In Harvey's conceptualization, urbanization

14. Harvey (2000) proposes the spatial fixes as a sort of escape valve for the internal pressures generated by the capitalist model, in which capitalists are constantly making use of imperialist practices to geographically reorganize the production chains and open new markets. 
is yet another internal factor that comes to favor globalization by concentrating "productive forces as well as labor power in space, transforming scattered populations and decentralized systems of property rights into massive concentrations of political and economic power" (Harvey, 2000, p. 25). But, very much like in other Marxist thinking, Harvey tells us that this strategy carries the seed of its own destruction, for eventually the "concentration of the proletariat in factories and towns makes them aware of their common interests. On this basis they begin to build institutions, such as unions, to articulate their claims" (p. 25).

In a nutshell, Harvey writes "that globalization has always been a specific project pursued and endorsed by particular powers in particular places that have sought and gained incredible benefits and augmentations of their wealth and power from freedoms of trade" (2000, p. 81).

Advancing to Harvey's central proposition for this analysis, a brief introduction to the uneven geographical developments of Harvey. These so-called uneven geographical developments are the result of the "fusion of these two elements of changing scales and the production of geographical differences" (2000, p. 79); the first one being the acceptance that scales are ever adapting systemic products of changing technologies, modes of human organization and political struggle; taking into consideration that none escape the influence of "so-called 'natural' components or influences" (2000, p. 75). The second one, the production of geographical differences, consists of a geographical mosaic or palimpsest, the result of the interaction between the past and present in the form of human interactions, historical legacies, and geographical components; "these changes have, however, become much more volatile in recent times, partially because of the qualitative shifts that have occurred within the process of globalization" (Harvey, 2000, p. 78).

It is worth noting that, in the midst of the interactions between the different scales, Harvey (2000) recognises that there is a Western universalizing factor, spread throughout the world, whom generates resistance from those communities who try to preserve their cultural identity.

In essence, Harvey's (2000) uneven geographical developments are the consideration of the interaction between the different socially constructed scales; a tool that can be employed to have an integral view of the effects of globalization over society and nature, a tool for planning in advance in the face of the potential repercussions that these interactions might have. 


\section{Geopolitical analysis of Confucianism in Vietnam}

In order to start with this geopolitical analysis, an appropriate good first step would be to remember Thayer's (2002) concept of the tyranny of geography, an entirely geopolitical term that deems Vietnam's geographic situation, as well as its demography and other factors, a tyrannical situation in which Vietnam's development will always be tied to its northern neighbor. A similar geopolitical interpretation would be the one by Fornillo (2016), who calls Vietnam and Ukraine extranjeros próximos [nearby foreigners] (p. 24), referring to their proximity to China and Russia respectively.

It goes without a doubt that China has been a determining factor in the development of contemporary Vietnam, especially when appreciating the vast amount of Chinese legacies within Vietnam. But it is also noteworthy that Vietnamese people took this Chinese influence and legacies and re-appropriated them in a way that was respectful with their own indigenous beliefs and norms, as writes Nghia (2005) about the assimilation of Confucianism into Vietnamese social norms. Very much in concordance with Hiep's phrase of "Vietnam has been willing to borrow culturally from China as long as it was a voluntary, internal process rather than a forceful imposition from the north" (2017, p. 16). A tendency that was also reflected in the multiple previously mentioned examples of local efforts to transmit Confucianism to every area of Vietnamese society throughout Vietnam's history.

Despite all of the aforementioned considerations, Vietnam has undergone some drastic changes in the last years. Going from a centrally planned economy to a market economy under the structural reform of 1986 referred to as Doi Moi, must have had some serious effects; and it has. Globalization, in its perpetual need to encompass every available market in its capitalistic process, rapidly permeated every sphere of Vietnamese society. This is not to say that previously Vietnam wasn't part of the global community, it was, but always under the influence of a foreign power; be it China, France, the United States or the Soviet Union, they all had, if not direct control, a very strong stand in deciding the course of Vietnam's internal affairs. It wouldn't be until the downfall of the Soviet Union and the implementation of the Doi Moi structural reforms that Vietnam would have a chance to delve, cautiously, into liberalism.

In a statement that reinforces the preceding affirmation, Nghia (2005) says: "having no chance to explore liberalism, the Vietnamese people bitterly 
learned of the dark side of capitalism. They therefore began to embrace socialism and socialist ideals under the influence of French colonialists" (p. 83).

An evidence of the recent incorporation of Vietnam into the global chains of production is the writing of Nir Avieli (2011), who mentions that "since the 1990s, when electricity became a regular feature in Hoi An, most Hoianese, urban and rural, have used electric rice cookers" (p. 222) and complements with "in the suburbs of Hoi An, where the dwellers were mostly farmers shifting into blue-collar and lower-middle-class urban jobs, traditional wood-fed hearths were gradually replaced by gas stoves and electric rice cookers" (p. 222). These quotes are clear proof of the overture that the Vietnamese regime had in the local scale.

Now, how can it be proven that in this maelstrom of changes brought about by globalization and its universalizing values, Confucian ones haven't been completely replaced? Could it be that, very much in accordance with the uneven geographical developments of Harvey's, urban areas are rapidly embracing the new Western universal values at the expense of Confucian ones?

There is historical evidence that shows that foreign influence has always been restricted to certain areas of Vietnam. As Nghia (2005) wrote about the seventeenth century in Vietnam, "foreign merchants settled in Pho Hien - North Vietnam - and Hoi An - South Vietnam — but left the country partly because of the hostile policies (...) - without being able to make any notable changes to the Vietnamese attitude towards the outside world" (p. 83).

Nevertheless, since the Doi Moi reforms there has been an accelerated transition of Vietnamese people from the countryside into urban areas, be it in the look for a job or to study and eventually get a job (Luong, 2018); all of it in a labor market that is, as Tran (2013) explains it, increasingly demanding of a workforce capable of providing their employers competitive skills. A more concrete evidence of this intense effect of globalization in Vietnamese society are the urbanization rates Vietnam's urbanization rates. Avieli wrote in 2011, referring to 1995 reports that "a total of 80 percent of the population live in the countryside and roughly 80-90 percent farm rice" (p. 221). According to the United Nations (2018), by the year 2000, the Vietnamese population that inhabited urban areas was $24.4 \%$, going up to $35.9 \%$ in the year 2018 , and projected to reach $57.3 \%$ by the year 2050 .

What better evidence of the pressure of globalisation over a specific society than ramping urbanisation rates and the rapid preparation of the people to 
enter the global labor market? ${ }^{15}$ What impact is it having on individuals and the traditional Vietnamese Confucian values, which involve loyalty to family?

To recapitulate, Nghia (2005) recognises the importance of agricultural life in Vietnam's social norms, and one of the features of agricultural life that ended up being assimilated into Vietnamese Confucianism is the Nhan-Nghia, which is the composition of two Vietnamese words that signify, accordingly, "a man's virtue", and the "obligation towards family and the community" (p. 81); together, Nhan-Nghia are the counterpart of the Chinese Confucian term of ren.

Having clarified the importance of family in Vietnamese Confucian tradition, it would be appropriate to signal that Vietnamese young people, who are the ones who tend to get urban jobs, still feel strongly attached to their families and communities.

A voice on the subject is Shibuya (2018) in his accounts of Long Tuyen villagers' testimonies; one particularly relevant is the one of an anonymous author who narrates how Mr. Duc believed in taking care of his parents and family, all whilst being witness of the accelerated changes in his community from 1990 onwards. Schwenkel (2011) wrote a brief interview she performed to Phuc and Thang who, despite showing little regard to Vietnam's history, still mentioned often using their free time to go back to their villages and visit their families; Schwenkel too talks about her friend Mai and her story of success in incorporating into the labor market, all whilst still having a strong sense of responsibility towards her family and their home on the outskirts of Hanoi. Not to mention Avieli (2011) and his explanation of implicit Confucian practices in the order in which Vietnamese people start eating rice, and Tran (2013) in her description of the importance of Confucian remnants in Vietnamese high education system.

All of these perspectives come to reinforce the fact that, despite the evident and rapidly developing effects of globalization in Vietnam, Confucianism still holds an important place in Vietnam's society; sometimes in detriment itself of the universal values that Western sourced globalization tends to bring with it.

And yet, Schwenkel (2011) points out that there is a perception of alarm and preoccupation amongst the older generations, reinforced by mass media

15. To this aspect, Luong (2018) says that "the exportation of labour from Vietnam increased from fewer than 100,000 persons annually in the early 1990s to 106,840 in 2014" (p. 602). 
and government discourse, that the younger generations are too accepting of capitalist values. To this, Schwenkel responds that "youth are not necessarily more apathetic about national traditions and revolutionary history, but have embraced new global market opportunities to carry out their familial and national duties more effectively" (p. 133).

Now, proceeding to a brief revisiting of geopolitical theory, we see that Vietnam does fit Harvey's (2000) uneven geographical developments: it is a country that joined the world in the globalization dynamics late - on the last part of the twentieth century-, its entrance immediately being followed by an avalanche of transformations and new foreign influences that would soon be seen reflected throughout societal scales; a quite notorious effect being the rapid urbanization and migration from the rural areas into the urban ones. Lastly, this new process and values brought by globalization have generated alarm amongst the older generations and government officials who claim to want to preserve Vietnamese culture.

As a response to this claim of abandoning Vietnamese culture, and to conclude this section, a quote on the subject from Christina Shwenkel, referring to her friend Mai, is very illustrative: "she [Mai] reminded me of how postwar generations, although seemingly indifferent to the state and its project of national history, still tend to emulate its moral values and traditions, and embrace its vision of an ideal and progressive modernity" (2011, p. 136).

\section{Final Considerations}

Even though cultural aspects did change over time, the main subject of this analysis, Confucianism and the manifestation of its values in Vietnamese society, remain there. The homogenizing and individualistic pressure from globalization hasn't had, or at least not yet, the effect of subverting the Confucian values. It could be said that the initial hypothesis of this analysis, being the possibility of globalization irreversibly having displaced Confucian values within Vietnamese society, has been discarded.

Nevertheless, it might be appropriate, given the evidence of rapid change within Vietnamese society, to remain vigilant of the future effects of the, Western in its origin, globalizing and universalizing process. 


\section{References}

Avieli, N. (2011). Eating Lunch and Recreating the Universe: Food and Cosmology in Hoi An, Vietnam. In K. M. Adams \& K. A. Gillogly (Eds.), Everyday Life in Southeast Asia (pp. 218-230). Indiana University Press.

Bidwell, D., \& Schipani, D. (2019). Interreligious Care in Totalitarian Contexts: Learnings from Cuba and Vietnam. In J. L. Snodgrass (Ed.), Navigating Religious Difference in Spiritual Care and Counseling: Essays in Honor of Kathleen J. Greider (Vol. 2, pp. 115-134). Claremont Press. https://doi. org/10.2307/j.ctvwrm4c3.11

Cuong, N. (2015). The Promotion of Confucianism in South Vietnam (19551975) and the Role of Nguyễn Đăng Thục as a New Confucian Scholar. Journal of Vietnamese Studies, 10(4), 30-81. https://doi.org/10.1525/ jvs.2015.10.4.30

Ebrey, P., Walthall, A., \& Palais, J. (2009). Modern East Asia: from 1600: A Cultural, Social, and Political History (2nd ed.). Houghton Mifflin Company.

Fornillo, B. (2016). China en la confrontación global del Pacífico (Integrar el sudeste asiático, inhibir el "giro estratégico" estadounidense y atraer al Sur global). In B. Fornillo, Sudamérica Futuro: China global, transición energética y posdesarrollo (Chico Mendes Collection, pp. 21-54). El Colectivo; CLACSO. https://doi.org/10.2307/j.ctvtxw23v

Gardner, D. (2014). Confucianism: A Very Short Introduction. Oxford University Press. https://doi.org/10.1093/actrade/9780195398915.003.0001

Harvey, D. (2000). Spaces of Hope. Edinburgh University Press.

Hiep, L. (2017). Living Next to the Giant: The Political Economy of Vietnam's Relations with China under Doi Moi. IsEAs-Yusof Ishak Institute.

Huang, C. (2018). Why Speak of "East Asian Confucianisms"? In R. T. Ames \& P. D. Hershock (Eds.), Confucianisms for a Changing World Cultural Order (Confucian Cultures Series, pp. 75-86). University of Hawai'i Press. https://doi.org/10.2307/j.ctv3zp05k.8

Kelley, L. (2006). "Confucianism" in Vietnam: A State of the Field Essay. Journal of Vietnamese Studies, 1(1-2), 314-370. https://doi.org/10.1525/ vs.2006.1.1-2.314

Luong, H. (2018). The Changing Configuration of Rural-Urban Migration and Remittance Flows in Vietnam. SOJOURN: Journal of Social Issues in Southeast Asia, 33(3), 602-646. https://www.jstor.org/stable/26538280 
Makeham, J. (2003). Introduction. In J. Makeham (Ed.), New Confucianism: A Critical Examination (pp. 1-21). Palgrave Macmillan.

Nghia, P. (2005). Confucianism and the conception of the law in Vietnam. In J. Gillespie, \& P. Nicholson (Eds.), Asian Socialism and Legal Change: The dynamics of Vietnamese and Chinese Reform (pp. 76-90). ANU Press. http:// doi.org/10.22459/ASLC.08.2005

Nguyen, N. (2018). The Noble Person and the Revolutionary: Living with Confucian Values in Contemporary Vietnam. In R. T. Ames \& P. D Hershock (Eds.), Confucianisms for a Changing World Cultural Order (Confucian Cultures Series, pp. 128-162). University of Hawai'i Press. https://doi. org/10.2307/j.ctv3zp05k.12

Paramore, K. (2015). “Civil Religion” and Confucianism: Japan's Past, China's Present, and the Current Boom in Scholarship on Confucianism. The Journal of Asian Studies, 74(2), 269-282. https://doi.org/10.1017/ S0021911814002265

Reilly, B. (2016). The Sovereign States of Vietnam, 1945-1955. Journal of Vietnamese Studies, 11(3-4), 103-139. https://doi.org/10.1525/jvs.2016.11.34.103

Schwenkel, C. (2011). Youth Culture and Fading Memories of War in Hanoi, Vietnam. In K. M. Adams \& K. A. Gillogly (Eds.), Everyday Life in Southeast Asia (pp. 127-136). Indiana University Press.

Shibuya, S. (2018). Urbanization, Jobs, and the Family in the Mekong Delta, Vietnam. Journal of Comparative Family Studies, 49(1), 93-108. https:// doi.org/10.3138/jcfs.49.1.93

Shin, D. (2011). Confucianism and Democratization in East Asia. Cambridge: Cambridge University Press. https://doi.org/10.1017/CBO9781139084086

Thayer, C. (2002). Vietnamese Perspectives of the 'China Threat'. In I. Storey $\&$ h. Yee (Eds.), The China Threat: Perceptions, Myths and Reality (pp. 270292). Routledge Curzon.

Tran, T. (2013). Limitation on the development of skills in higher education in Vietnam. Higher Education, 65(5), 631-644. https://doi.org/10.1007/ s10734-012-9567-7

United Nations. (2018). World Urbanization Prospects 2018. https://population.un.org/wup/Country-Profiles/

Van Anh, L. (2006). Adapting to Globalization in Vietnam: Seeking Development in the Global Economy. In J. Dator, D. Pratt \& Y. Seo (Eds.), Fairness, 
Globalization, and Public Institutions: East Asia and Beyond (pp. 312-318). University of Hawai'i Press. https://doi.org/10.2307/j.ctv3zp081.27 